\title{
How prior economic education influences beginning university students' knowledge of economics
}

\author{
Roland Happ ${ }^{*}$, Olga Zlatkin-Troitschanskaia ${ }^{1}$ and Manuel Förster ${ }^{2}$
}

\author{
*Correspondence: \\ roland.happ@uni-mainz.de \\ 1 Department of Law, \\ Business \& Economics, Chair \\ of Business and Economics \\ Education, Johannes \\ Gutenberg University \\ Mainz, Jakob-Welder-Weg 9, \\ 55128 Mainz, Germany \\ Full list of author information \\ is available at the end of the \\ article
}

\begin{abstract}
Background: When beginning higher education studies in business and economics students bring with them diverse knowledge and experience in the field, which could affect their success in the program. Differences in prior economic education pose challenges to the teachers in higher education as they have to decide which knowledge of economics the students have. This is important for preparing the lessons in higher education. In this paper, we investigate how prior economic education influences beginning university students' knowledge of economics.

Methods: We administered items from the German adaptations of the test of economic literacy and the test of understanding college economics, both developed by the national council on economic education, to assess the general knowledge of economics and specific knowledge of micro- and macroeconomics of 511 beginning students at two universities in Germany.
\end{abstract}

Results: Participants who had completed vocational training or a course in economics as a major subject at secondary school ("Leistungskurs Wirtschaft") performed significantly better on items relating to general economics and macroeconomics; however, there was no significant difference in performance on items relating to microeconomics between the comparison groups. Attendance of an upper secondary school specializing in economics ("Wirtschaftsgymnasium") has no significant effect when controlling for these two learning opportunities and other personal characteristics. In addition, we performed regression-analytic modelling to examine the correlation between economic knowledge and personal factors such as gender, grade on university entrance examination, and migration background and found effects depended on the economic content area assessed.

Conclusions: The study demonstrates that there is a heterogeneity in students' knowledge of economics when beginning higher education studies in business and economics. The results of this research highlight the importance of designing targetoriented teaching methods that take into consideration the study-relevant (prior) knowledge of beginning students.

Keywords: Vocational training, Course in economics as a major subject, Upper secondary school specializing in economics, Prior economic education, Business and economics, Test of economic literacy, Test of understanding college economics, Heterogeneity, Beginning university students 


\section{Problem}

Beginning students of business and economics differ in the education they obtained before starting their university programs in economics: While some have completed vocational training, ${ }^{1}$ others have completed courses in economics as a major subject at secondary school (Bouley et al. 2015; Brückner et al. 2015b; Hillmert and Jacob 2003). Similarly, it is possible for the upper classes of secondary school (typically school years 11-13 or 11-12), students attended an upper secondary school specializing in economics ("Wirtschaftsgymnasium") rather than a standard upper secondary school ("allgemeinbildendes Gymnasium") (Chang 2005; Georg 2014). In their internationally established model of study success, Kuh et al. (2007) show the correlation between learning opportunities taken prior to beginning studies and beginning students' knowledge upon starting their studies. Although investigation has been made into the impact of having completed vocational training (Beck and Krumm 1994; Brückner et al. 2015b; Happ et al. 2016b; Van den Berg and Hofman 2005), a course in economics as a major subject at secondary school (Brasfield et al. 1993; Gill and Gratton-Lavoie 2011; Shim et al. 2009; Walstad et al. 2007) or attendance of an upper secondary school specializing in economics (Sczesny and Lüdecke-Plümer 1998) on knowledge of economics, these student-related variables generally have been examined in isolation of each other. From a learning-theoretical perspective, it could be assumed that students use their prior knowledge of economics to create a mental representation of economics-related problems. The more formal education in economics students have obtained prior to starting their university studies in economics, the greater their knowledge of economics is when they begin their studies. In this paper investigation is made into the extent to which prior education in economics accounts for study-relevant knowledge upon beginning university studies. Further, investigation is made into whether the (test-based) assessed level of knowledge of economics differs systematically between beginning students of business and economics that have had such prior educational experiences (i.e., completed vocational training and/or a course in economics as a major subject at secondary school and/or attendance of an upper secondary school specializing in economics) and beginning students that have not (for a model of knowledge of business and economics, see Zlatkin-Troitschanskaia et al. 2014). The results of this research will provide important insight for designing target-oriented teaching methods that take into consideration the study-relevant knowledge of beginning students (cf. contributions in Hoyt and McGoldrick 2012).

To determine exactly how prior economic knowledge differs among beginning students, a measurement instrument needs to include items that accurately assess general knowledge of economics at a basic level and items that assess more specific knowledge of economics at an in-depth level (Dochy et al. 1999; Hailikari 2009; Yousfi and Böhme 2012). In this study, for the first time, items from two measurement instruments - the German adaptation of the fourth version of the American test of economic literacy (TEL4-G, see Happ et al. 2016a; for the original American version, see Walstad et al. 2013) and the German adaptation of the fourth version of the American test of

\footnotetext{
${ }^{1}$ According to the German Centre for Higher Education Research and Science Studies the proportion of new students enrolled who had obtained pre-study vocational training was $22 \%$ in the winter term 2011/2012 (Scheller et al. 2013).
} 
understanding college economics (TUCE4-G, see Zlatkin-Troitschanskaia et al. 2016; for the original American version, see Walstad and Rebeck 2008)-are used to assess the knowledge of economics of beginning university students enrolled in business and economics programs at two universities in Germany. Combining items from these two instruments allows knowledge of the main content areas of economics (i.e., basics of economics, microeconomics, and macroeconomics; for a nationwide curricular analysis of the content areas, see Zlatkin-Troitschanskaia et al. 2016) and knowledge at various levels to be assessed separately. As a result, the effects of the three learning opportunities (vocational training and/or a course in economics as a major subject at secondary school and/or attendance of an upper secondary school specializing in economics) can be analyzed according to content area. First, the theoretical basis of this study is explained ("Theoretical basis and hypotheses" section). Second, the selection and setup of two test instruments used in the operationalization of economic knowledge and the sample are described ("Test instrument and sample" section). Third, through the calculation of $t$ tests and multiple linear regression models, the impact of having completed vocational training and/or a course in economics as a major subject at secondary school and/or attendance of an upper secondary school specializing in economics on economic knowledge prior to beginning higher education studies in economics is assessed ("Results" section). Lastly, the findings and limitations of the study are discussed and conclusions for further research are provided ("Discussion" and "Conclusions" sections).

\section{Theoretical basis and hypotheses}

\section{Economic knowledge and understanding}

According to the results of the Germany-wide analyses of higher education economics curricula conducted by Zlatkin-Troitschanskaia et al. (2015) and current higher education economics textbooks conducted by Happ et al. (2016b), economic knowledge comprises the main content areas of general economic knowledge, microeconomic knowledge, and macroeconomic knowledge. This classification is based on the established curriculum and the structure presented in current economics textbooks (e.g., Krugman and Wells 2013; Mankiw and Taylor 2011; Samuelson and Nordhaus 2010). General economic knowledge consists of basic economic concepts such as the principles of scarcity and opportunity costs and can be distinguished from more specific microeconomic and macroeconomic knowledge (OECD 2011). Therefore, a test instrument that serves to operationalize knowledge of economics needs to assess these three main content areas of economics (for a model of knowledge of economics, see Zlatkin-Troitschanskaia et al. 2014).

\section{Factors that influence the knowledge of economics of beginning university students} Completion of vocational training and/or a course in economics as a major subject in secondary school and/or upper secondary school specializing in economics

In several studies differences in the knowledge of economics of beginning students have been found to be rooted in learning opportunities taken before starting university studies (e.g., Happ et al. 2016b). The curricula of vocational training programs in commercial administration, for example, for apprentices in industrial management assistance and banking, and relevant textbooks address economics-related topics (e.g., Hartmann 
2015, for industrial management assistant; Möhlmeier et al. 2015, for bank business management assistant). If beginning students have completed commercial-administrative vocational training before starting their university studies, they can be expected to have greater knowledge and understanding of economics than those who have not had such training (hypothesis 1).

Not only apprentices in commercial-administrative vocational training programs but also senior students at secondary schools who have completed an economics course as a major subject in secondary school learn about economics-related topics. For example, in the state of Hesse topics such as economic production factors and the macro-economic process, the economic principle and determinants of economic growth are addressed in the curricula of a major economics course. Furthermore, the textbooks used in this schooling context also indicate that fundamental economic contents are already conveyed at this stage (e.g., Lorz and Siebert 2007; for exemplary textbook recommendations by the state of Rhineland-Palatinate see Pedagogical State Institute Rhineland-Palatinate 2018). Thus, it can be assumed that graduates who have completed a course in economics as a major subject have greater knowledge and understanding of economics than students who have not completed a course in economics as a major subject (hypothesis 2).

In Germany the degree of specialization of the different school types varies by state (Eckhardt and Eurydice 2017). In Rhineland-Palatinate and Hesse, which are the German states the empirical part of this paper focuses on, higher education entrance qualification can be obtained at a specialized upper secondary school as well as at standard secondary school. As the present paper focuses on economic knowledge, upper secondary schools specializing in economics are of particular interest. ${ }^{2}$ In view of the textbooks recommended for vocational schools, clear differences can be seen in comparison to the textbooks recommended for non-specialized schools. This is the case in Hesse, for example (for standard school textbook recommendations, see Hessian Ministry for Education and Cultural Affairs 2017b; for vocational school textbook recommendations, see Hessian Ministry for Education and Cultural Affairs 2017a). When contrasting school textbook recommendations for the vocational school sector (for Rhineland-Palatinate, see, e.g., Distel et al. 2014; Lüpertz 2018) with the textbook recommendations for the non-specialized school sector (for Rhineland-Palatinate, see, e.g., Bauer et al. 2016; Engelhart 2010), certain differences become apparent. The recommendations for the vocational school sector include far more textbooks on economic topics, while the economics-specific textbooks recommended for the non-specialized sector tend to address rather political topics and tend to focus less on business and economics (Hessian Ministry for Education and Cultural Affairs 2017b, p. 20). With regard to curricula, upper secondary schools specializing in economics present a stronger focus on economic contents. It can therefore be assumed that the economic knowledge of students who attended an upper secondary school specializing in economics differs from that of standard upper secondary school students (hypothesis 3).

Previous research has already highlighted differences between beginning students from standard and economics-oriented upper secondary schools, indicating that the

\footnotetext{
2 Besides upper secondary schools focussing on economics, there are also schools specializing in technology and engineering and health and social matters (for Rhineland-Palatinate, see Ministry for Education 2017).
} 
two school types attract different types of school graduates. Trautwein et al. (2007) point out, that students of standard upper secondary schools show a higher level of general basic cognitive abilities than students from upper secondary schools specializing in economics. Many studies have identified basic cognitive abilities as particularly relevant for knowledge acquisition in general (e.g., Prins et al. 2006) as well as for the acquisition of economic knowledge in particular (e.g., Happ et al. 2016b). Therefore, the effects of general cognitive abilities on economic knowledge are controlled for in both groups of students.

\section{Control variables}

In analyses of the impact of having completed commercial-administrative vocational training and/or a course in economics as a major subject at secondary school and/or attendance of an upper secondary school specializing in economics on knowledge of economics, various other person-related variables of the participants such as gender need to be examined in regression modelling to avoid bias in estimations (Parker 2006). Hence, results of many surveys indicate that male participants have an advantage on standardized tests of knowledge of economics (e.g., Asarta et al. 2014; Brückner et al. 2015b; Förster et al. 2015b; Gill and Gratton-Lavoie 2011; Happ et al. 2016a; Walstad and Rebeck 2008), which is why gender should be considered in the modelling. Hurrelmann (2009) found that secondary school students in Germany with a migration background had a lower level of knowledge of economics than students with no migration background. Moreover, Brückner et al. (2015a) and Happ et al. (2016a) found students in Germany whose mother tongue was not German had a lower level of knowledge of economics. Consequently, it can be assumed that the participants' levels of economic knowledge differ according to whether or not they have a migration background, which is why this person-related variable also should be investigated. A student's grade upon leaving school is of paramount importance as it is the most common criterion for admission to universities in Germany (see Uthmann 2009). This is linked to the expectation that a student's final grade correlates with his or her intellectual abilities. In several studies a correlation has been found between secondary school GPA and students' knowledge of economics (see, e.g., Anderson et al. 1994; Walstad et al. 2013). Hence, participants' final grades should be taken into account.

\section{Test instrument and sample}

\section{Operationalization of economic knowledge and influential factors}

There are several instruments for assessing economic knowledge that would be suitable for the target group of beginning students. For example, in the German-speaking context, the WBT (Wirtschaftskundlicher Bildungstest) by Beck et al. (1998) and the tasks used in the OEKOMA project by Schumann et al. (2013) should be mentioned. In terms of English-language instruments, there are the major field tests (MFT) by the Educational Testing Service (ETS 2014), the NAEP Economics Framework by the National Center for Education Statistics (NCES 2006) and the economics tasks from the Assessment of Higher Education Learning Outcomes (AHELO) by the OECD (2011). In the Spanish-speaking context, there is the Exámenes Generales de Egreso de la Licenciatura (EGEL) (specifically for the field of economics: Economiá) by the Centro Nacional de 
Evaluación para la Educación Superior (CENEVAL 2013; Vidal 2013) (for a more detailed overview, see Zlatkin-Troitschanskaia et al. 2017). Some of these instruments are already relatively old and the topicality of their items should be critically reassessed in view of updating beginning students' curricula. ${ }^{3}$

Due to the different economic learning opportunities before the beginning of studies, a high heterogeneity in economic knowledge among participants is to be expected. Therefore, items of varying difficulty levels from several instruments were purposely selected, also considering content differentiation (see "Economic knowledge and understanding"). The items for operationalizing knowledge of economics in this study come from two validated test instruments that were adapted into German. To determine participants' (1) general knowledge of economics, items from the fourth (German) version of the American test of economic literacy (TEL4-G) were used. The original TEL4 was constructed with two parallel versions A and B, each consisting of 45 items (Walstad et al. 2013). Approximately $40 \mathrm{~min}$ is needed to complete each version. The two versions are linked via 10 anchor items. The items from the TEL4 were translated into German and adapted to suit the German context (for the adaptation process, see Förster et al. 2015a). In this study, 10 items relating to the basic system of economics were selected from the TEL4-G to assess students' general knowledge of economics. These ten items cover basic principles such as scarcity and the principle of opportunity costs. Both test version A and $B$ of the TEL4-G were used in a study conducted in Germany in the summer semester of 2014 with a total of 1397 economics students. The short version of the TEL4-G used for the present paper shows a Pearson correlation of $.85(\mathrm{p}=.000)$ with the full scale of version $\mathrm{A}$ and $.84(\mathrm{p}=.000)$ with version $\mathrm{B}$. Therefore, the correlation between the total score of the TEL4-G and the short is high, which means that the ten selected items are representative of the information in the full test. The items' reliability is acceptable, with a Cronbach's alpha of .62 for ten dichotomous items (Happ et al. 2017).

To assess beginning students' knowledge of (2) microeconomics and (3) macroeconomics, items from the fourth (German) version of the American test of understanding college economics (TUCE4-G) were used. The original TUCE consists of two parts: microeconomics and macroeconomics (Walstad and Rebeck 2008). Each part has 30 multiple-choice items and takes approximately $30 \mathrm{~min}$ to complete. The TUCE was translated into German and adapted to suit the German context for use in the WiWiKom I project (Zlatkin-Troitschanskaia et al. 2014). Due to test time restrictions and expectable fatigue effects during test-taking it was not possible to let every participant complete both versions of the TUCE4-G in addition to the ten items from the TEL4-G. Therefore, this study resorted to a test booklet design, for which two versions of a questionnaire were constructed. ${ }^{4}$ While both versions had 10 items from the TEL4-G concerning general knowledge of economics, one version had all 30 items from

\footnotetext{
${ }^{3}$ At the same time, for copyright reasons, not all instruments are freely accessible, which inhibited their full use for the present study.

4 After consultation with the test developers, a decision was made against creating short versions of the two TUCE versions as there would be no guarantee for maintaining the quality standards (such as scale reliability and validity of test score interpretations). The reliability when using the TUCE in the present study has a Cronbach's alpha of .64 (TUCE4G macroeconomics) and .58 (TUCE4-G microeconomics). As later findings show, the TUCE4-G can be considered rather difficult for participants in their first semester. In order to cover the expected range of economic knowledge at the beginning of studies, the present study used both the TUCE4-G and the TEL4-G.
} 
the TUCE4-G concerning microeconomics and the other version had all 30 items concerning macroeconomics. Hence, each instrument to assess participants' knowledge of economics consisted of 40 items. The order of the items was different in each of the two versions of the questionnaire to avoid position effects. This means that in one version of the questionnaire the participants were presented with items 1-40 and in the other with items $40-1$.

On the personal data part of the questionnaire, participants first reported on whether they had completed commercial-administrative vocational training and/or a course in economics as a major subject at secondary school and/or attendance of an upper secondary school specializing in economics. Then, they reported on their gender, final grade, and migration background. To determine possible migration background, participants were asked about their parents' place of birth and the language used at home. These two indicators have formed the basis for the operationalization of migration background in numerous studies in education (Klein et al. 2014; Kristen et al. 2008; Salentin 2014; Sugarman et al. 2016).

\section{Sample}

In a paper-pencil questionnaire 511 beginning students of business and economics at two universities in Germany were surveyed at the beginning of the winter semester 2014/15. All 511 students responded to the 10 items from the TEL4-G concerning general economics, 260 students responded to the 30 items concerning microeconomics from the TUCE4-G, and 251 students responded to the 30 items concerning macroeconomics from the TUCE4-G. Table 1 provides an overview of the sample:

As can be seen in Table 1, 20.5\% of the participants had completed vocational training, more than a third (35.2\%) of participants had completed a course in economics as a major subject at secondary school and $29.7 \%$ attended an upper secondary school specializing in economics. 5.7\% $(\mathrm{N}=29)$ of participants had completed both vocational training and a course in economics as a major subject at secondary school. The overlap between participants who attended an upper secondary school specializing in economics and those who completed a vocational training or an economics course as a major subject is remarkably high. $46.7 \%(\mathrm{~N}=49)$ of participants who completed a vocational training had previously attended an economics-oriented upper secondary school and 49.2\% $(\mathrm{N}=88)$ of participants who had economics as a major course had also attended a specialized upper secondary school. The distribution of person-related variables (gender, final grade, migration background) complied with the usual distribution among beginning business and economics students (Federal Statistical Office 2016). Therefore, no systematic distortions can be assumed in the sample (for limitations, see "Discussion" section).

\section{Results}

\section{Analysis of cross-classification}

In line with the results of research presented in "Theoretical basis and hypotheses" section it can be assumed that the covariates gender, migration background, and final grade will influence participants' scores in all three content areas. In Table 2 a cross-classification illustrates the descriptive distribution of these three covariates for the three 
Table 1 Descriptive statistics of the sample

\begin{tabular}{|c|c|c|c|c|c|c|}
\hline \multirow[t]{2}{*}{ Sample size } & \multicolumn{2}{|c|}{ Total sample } & \multicolumn{2}{|c|}{$\begin{array}{l}\text { Subsample macro } \\
\text { score }\end{array}$} & \multicolumn{2}{|c|}{$\begin{array}{l}\text { Subsample } \\
\text { micro score }\end{array}$} \\
\hline & Absolute & In percentage & Absolute & $\%$ & Absolute & $\%$ \\
\hline Number of students & 511 & 100 & 251 & 100 & 260 & 100 \\
\hline \multicolumn{7}{|l|}{ Course in economics as major } \\
\hline No course in economics as major & 328 & 64.2 & 150 & 59.8 & 178 & 68.4 \\
\hline Course in economics as major & 180 & 35.2 & 101 & 40.2 & 79 & 30.4 \\
\hline Missing values & 3 & 6 & - & - & 3 & 1.2 \\
\hline \multicolumn{7}{|c|}{ Attendance of an upper secondary school specializing in economics } \\
\hline Standard upper secondary school & 358 & 70.1 & 170 & 67.7 & 188 & 72.3 \\
\hline $\begin{array}{l}\text { Upper secondary school special- } \\
\text { izing in economics }\end{array}$ & 152 & 29.7 & 81 & 32.3 & 71 & 27.3 \\
\hline Missing values & 1 & .2 & - & - & 1 & .4 \\
\hline \multicolumn{7}{|l|}{ Vocational training } \\
\hline No vocational training & 405 & 79.3 & 206 & 82.1 & 199 & 76.5 \\
\hline Vocational training & 105 & 20.5 & 44 & 17.5 & 61 & 23.5 \\
\hline Missing values & 1 & .2 & 1 & .4 & - & - \\
\hline \multicolumn{7}{|l|}{ Gender } \\
\hline Female & 266 & 52.1 & 134 & 53.4 & 132 & 50.8 \\
\hline Male & 245 & 47.9 & 117 & 46.6 & 128 & 49.2 \\
\hline Missing values & - & - & - & - & - & - \\
\hline \multicolumn{7}{|l|}{ Migration background } \\
\hline Migration background & 155 & 30.3 & 75 & 29.9 & 80 & 30.8 \\
\hline No migration background & 354 & 69.3 & 175 & 69.7 & 179 & 68.8 \\
\hline Missing values & 2 & .4 & 1 & .4 & 1 & .4 \\
\hline \multicolumn{7}{|l|}{ Mean } \\
\hline Final grade ${ }^{a}$ & & $2.4(.53)$ & $2.4(.51)$ & & $2.4(.54)$ & \\
\hline Missing values & 7 & 1.4 & 2 & .8 & 5 & 1.9 \\
\hline
\end{tabular}

Standard deviations are in parentheses

a Better grades are represented by lower numbers in the German grading system ( 1 = best grade; $4=$ lowest passing grade)

learning opportunities "completed vocational training", "course in economics as a major" and "attendance of an upper secondary school specializing in economics".

As can be seen in Table 2, there was only a slight difference in completion of vocational training between the genders. Gender differences were significantly larger among participants who had completed a course in economics as a major subject at secondary school as well as among those who had attended of an upper secondary school specializing in economics. The percentage of male participants who had attended a specialized upper secondary school or completed a major economics course is higher than the respective percentage of female participants. Far fewer participants with a migration background (13.5\%) had completed vocational training in comparison to participants with no migration background (23.5\%). The number of students with a migration background and the number of students without a migration background who had completed a course in economics as a major subject at secondary school was about the same. However, this is not the case with attendance of an upper secondary school specialized in economics.

${ }^{5}$ All analyses presented in the paper were conducted using the software SPSS Version 23 (IBM Corp 2014). 
Table 2 Cross-classification of learning opportunities and covariates

\begin{tabular}{|c|c|c|c|c|c|}
\hline & \multicolumn{2}{|l|}{ Gender } & \multicolumn{2}{|c|}{ Migration background } & \multirow[t]{2}{*}{ Final grade } \\
\hline & Female & Male & $\begin{array}{l}\text { No migration } \\
\text { background }\end{array}$ & $\begin{array}{l}\text { Migration } \\
\text { background }\end{array}$ & \\
\hline No vocational training & $\begin{array}{l}213 \\
80.1 \%^{a}\end{array}$ & $\begin{array}{l}192 \\
78.7 \%^{\mathrm{a}}\end{array}$ & $\begin{array}{l}270 \\
76.5 \% \text { b }\end{array}$ & $\begin{array}{l}134 \\
86.5 \% \text { b }\end{array}$ & $\begin{array}{l}400 \\
2.36\end{array}$ \\
\hline Vocational training & $\begin{array}{l}53 \\
19.9 \%^{a}\end{array}$ & $\begin{array}{l}52 \\
21.3 \%^{\mathrm{a}}\end{array}$ & $\begin{array}{l}81 \\
23.5 \%{ }^{b}\end{array}$ & $\begin{array}{l}21 \\
13.5 \%{ }^{b}\end{array}$ & $\begin{array}{l}103 \\
2.54\end{array}$ \\
\hline Total & $\begin{array}{l}266 \\
100 \%{ }^{a}\end{array}$ & $\begin{array}{l}244 \\
100 \%{ }^{a}\end{array}$ & $\begin{array}{l}353 \\
100 \% \text { b }\end{array}$ & $\begin{array}{l}155 \\
100 \%{ }^{b}\end{array}$ & $\begin{array}{l}503 \\
2.40\end{array}$ \\
\hline No course in economics as a major & $\begin{array}{l}185 \\
69.5 \%^{\mathrm{a}}\end{array}$ & $\begin{array}{l}143 \\
59.1 \%^{\mathrm{a}}\end{array}$ & $\begin{array}{l}266 \\
64 \%^{b}\end{array}$ & $\begin{array}{l}100 \\
65.4 \%^{b}\end{array}$ & $\begin{array}{l}323 \\
2.39\end{array}$ \\
\hline Course in economics as a major & $\begin{array}{l}81 \\
30.5 \%{ }^{\mathrm{a}}\end{array}$ & $\begin{array}{l}99 \\
40.9 \%^{a}\end{array}$ & $\begin{array}{l}127 \\
36 \%^{b}\end{array}$ & $\begin{array}{l}53 \\
34.6 \% \text { b }\end{array}$ & $\begin{array}{l}178 \\
2.41\end{array}$ \\
\hline Total & $\begin{array}{l}266 \\
100 \%{ }^{a}\end{array}$ & $\begin{array}{l}242 \\
100 \%{ }^{a}\end{array}$ & $\begin{array}{l}353 \\
100 \%{ }^{b}\end{array}$ & $\begin{array}{l}153 \\
100 \% \text { b }\end{array}$ & $\begin{array}{l}501 \\
2.40\end{array}$ \\
\hline Standard upper secondary school & $\begin{array}{l}195 \\
73.3 \%{ }^{\mathrm{a}}\end{array}$ & $\begin{array}{l}163 \\
66.9 \%^{a}\end{array}$ & $\begin{array}{l}261 \\
73.9 \% \text { b }\end{array}$ & $\begin{array}{l}95 \\
61.3 \%{ }^{b}\end{array}$ & $\begin{array}{l}353 \\
2.37\end{array}$ \\
\hline $\begin{array}{l}\text { Attendance of an upper secondary } \\
\text { school specializing in economics }\end{array}$ & $\begin{array}{l}71 \\
26.7 \%{ }^{\mathrm{a}}\end{array}$ & $\begin{array}{l}81 \\
33.2 \%^{\mathrm{a}}\end{array}$ & $\begin{array}{l}92 \\
26.1 \% \%^{b}\end{array}$ & $\begin{array}{l}60 \\
38.7 \% \%^{b}\end{array}$ & $\begin{array}{l}150 \\
2.47\end{array}$ \\
\hline Total & $\begin{array}{l}266 \\
100 \%{ }^{a}\end{array}$ & $\begin{array}{l}244 \\
100 \%\end{array}$ & $\begin{array}{l}353 \\
100 \%\end{array}$ & $\begin{array}{l}155 \\
100 \%\end{array}$ & $\begin{array}{l}503 \\
2.4\end{array}$ \\
\hline
\end{tabular}

a $\%$ in the gender variable

b $\%$ in the migration background variable

Participants with a migration background (38.7\%) attended this school type far more often than participants without a migration background (26.1\%). Participants from specialized upper secondary schools only had a marginally worse final grade $($ mean $=2.47)$ than participants from standard upper secondary schools (mean $=2.37$ ). These descriptive findings (Table 2) highlight the importance of controlling for personal characteristics such as migration background or gender in further analyses.

\section{Histograms and t-tests}

Analyses of participants' scores on the 10 items from the TEL4-G concerning basics of economics, the 30 items from the TUCE4-G concerning microeconomics, and the 30 items from the TUCE4-G concerning macroeconomics were analyzed separately. The distribution of the three scores in the sample was examined using a histogram. First, the number of missing values in the performance data was considered. The respondents with more than $50 \%$ in missing values, that is, unanswered items in one of the three content areas, were excluded from analyses. Accordingly, seven participants were excluded from further analyses for the TEL4-G items, four were excluded from analyses of the TUCE4-G microeconomics items, and one was excluded from analyses of the TUCE4-G macroeconomics items.

On average, the 504 beginning students obtained 6.6 of a maximum of 10 points on the TEL4-G items (SD: 1.831). This means that, on average, they responded to more than half of the items relating to general knowledge of economics correctly. Results of the Kolmogorov-Smirnov test $(\mathrm{p}=.000)$ and the Shapiro-Wilk test $(\mathrm{p}=.000)$ indicate that the assumption that distribution was normal must be rejected (see Fig. 1). However, with regard to skewness $(-.470)$ and kurtosis $(-.217)$, the deviations of the 


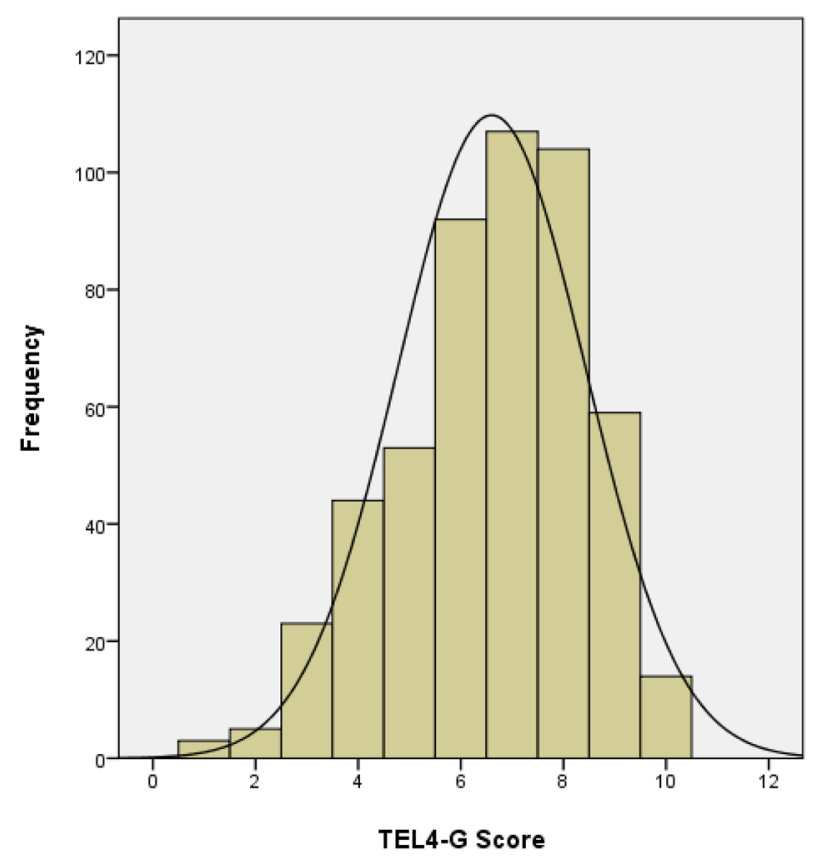

Fig. 1 Histogram for the TEL4-G score

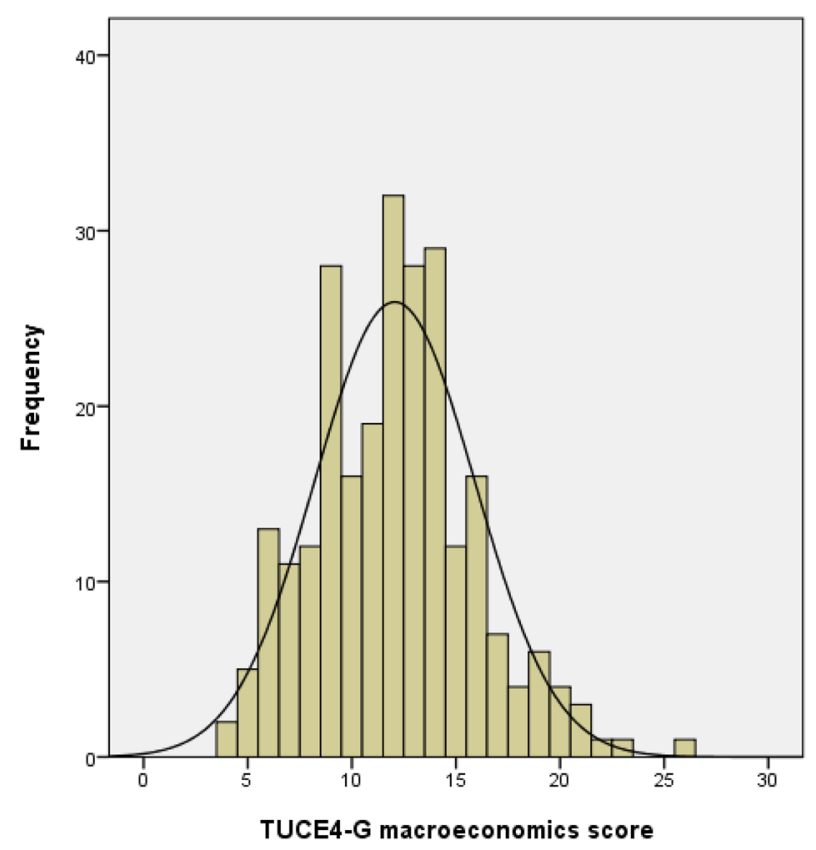

Fig. 2 Histogram of scores on TUCE4-G items concerning macroeconomics

curve from the normal distribution were not considered to be great. Accordingly, the distribution can be characterized as being fairly normal (Chou and Bentler 1995; Curran et al. 1996; Gravetter and Wallnau 2014; Ho and Yu 2015). 


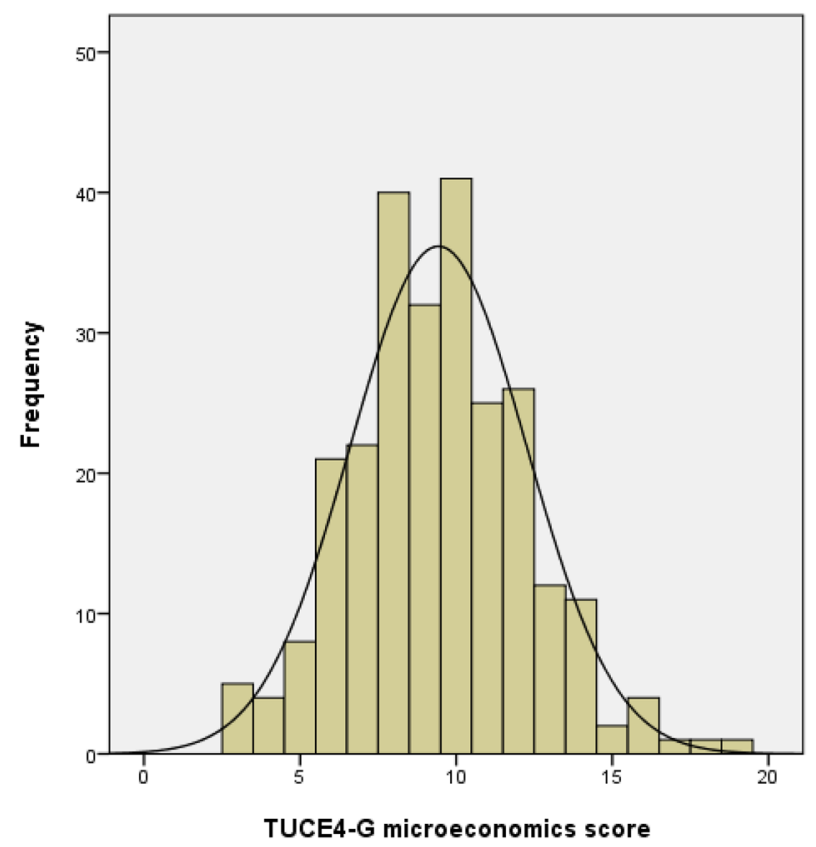

Fig. 3 Histogram of scores on TUCE4-G items concerning microeconomics

The histogram (see Fig. 2) for the score on the macroeconomics part of the TUCE4-G indicates that the 250 participants responded correctly to an average of 12.06 of the 30 items (SD: 3.844). As expected, the TUCE4-G items concerning macroeconomics were more difficult for the participants than the TEL4-G items. Overall, participants were only able to successfully solve fewer than half the items in this test. It should be noted, however, that some participants were able to score more than 25 points in this test (see Fig. 2).

Results of the Kolmogorov-Smirnov test $(\mathrm{p}=.000)$ and the Shapiro-Wilk test $(\mathrm{p}=.001)$ indicate that the distribution of the scores on the TUCE4-G items concerning macroeconomics was not normal. However, when skewness (.392) and kurtosis (.297) were taken into consideration, the scores on the TUCE4-G items concerning macroeconomics had a fairly normal distribution.

When examining the distribution of the scores on the 30 TUCE4-G items concerning microeconomics, it is noticeable that with an average of 9.43 points (SD: 2.823) this part of the test was the most difficult for the 256 beginning students. On average, participants solved less than a third of the items correctly. Therefore, the test part of TUCE4-G concerning microeconomics is even more difficult for the participants than the TUCE4G macroeconomics test. On this test, no participant was able to solve more than twothirds of the test items correctly. Results of the Kolmogorov-Smirnov test $(\mathrm{p}=.000)$ and the Shapiro-Wilk test $(\mathrm{p}=.002)$ indicate that the distribution of the scores on the microeconomics part of the test was not normal. However, the distribution can be considered as relatively normal when examining the skewness (.284) and kurtosis (.340) (see Fig. 3).

To investigate the main question in this study (see "Problem" section "To what extent does prior education in economics account for study-relevant knowledge upon beginning university studies?"), $\mathrm{t}$ tests for each of the three scores for independent samples 
Table 3 T-tests for the different learning opportunities

\begin{tabular}{llll}
\hline & TEL4-G score & $\begin{array}{l}\text { TUCE4-G } \\
\text { macroeconomics } \\
\text { score }\end{array}$ & $\begin{array}{l}\text { TUCE4-G } \\
\text { microeconomics } \\
\text { score }\end{array}$ \\
\hline Without vocational training & & 11.80 & 9.28 \\
With vocational training & 6.44 & 13.14 & 9.93 \\
& 7.18 & $p=.035$ & $p=.119$ \\
Without course in economics as major & $\mathrm{p}=.000$ & $\mathrm{~d}=.352$ & .231 \\
With course in economics as major & 6.40 & 11.33 & 9.32 \\
& 6.96 & 13.13 & 9.65 \\
Standard upper secondary school & $\mathrm{d}=.001$ & $\mathrm{p}=.000$ & $\mathrm{p}=.387$ \\
Secondary school specializing in economics & 6.59 & $\mathrm{~d}=.48$ & $\mathrm{~d}=.117$ \\
& $\mathrm{~d}=.308$ & 11.93 & 9.45 \\
& 6.6 & 12.31 & 9.35 \\
\end{tabular}

were conducted (see Elliott and Woodward 2007; Moore and McCabe 2003). Results for the participants who had had no vocational training were compared to those for the participants who had. Also, results for the participants who had completed a course in economics as a major subject at secondary school were compared to the results for participants who had not. Similarly, students from economics-oriented upper secondary schools were compared to students from standard upper secondary schools. The effect size of Cohen's $d^{6}$ was calculated in order to measure the strength of the relationship. The results of the t-tests are shown in Table 3 .

Results of the t-tests reveal highly significant differences in the mean values of the scores on the TEL4-G items concerning basics of economics between students with and students without vocational training and students with and without a course in economics as a major subject. The effect size of having completed vocational training (Cohen's $\mathrm{d}=.41$ ) and a course in economics as a major subject (Cohen's $\mathrm{d}=.308$ ) was small. A significant gap in knowledge of macroeconomics, as indicated in responses to items from the TUCE4-G, also was found between students with and students without the two learning opportunities. Cohen's d of .352 for vocational training completed and .48 for completing a course in economics as a major subject at secondary school indicate a small to medium effect size. The beginning students who had completed vocational training or a course in economics as a major subject at secondary school achieved higher scores on the TUCE4-G items concerning microeconomics than beginning students who had had neither of the two learning opportunities. However, the findings are not significant, and the values of the effect size are very low (Cohen's $d$ vocational training $=.231$; economics course $=.117)$. Findings in regard to the attendance of an upper secondary school specializing in economics demonstrate: Neither the TEL4-G nor the TUCE4-G test scores show significant or, in view of the effect size Cohen's d, meaningful differences between students from the two school types (Table 3).

${ }^{6}$ Values of Cohen's $\mathrm{d}$ effect size can be tiny $(\mathrm{d}<.3)$, small $(\mathrm{d}<.5)$, medium (from $\mathrm{d}>.5$ to $\mathrm{d}<.8$ ) or large $(\mathrm{d}>.8)$ (see Cohen 1988). 
Table 4 Multiple linear regression models based on economic knowledge

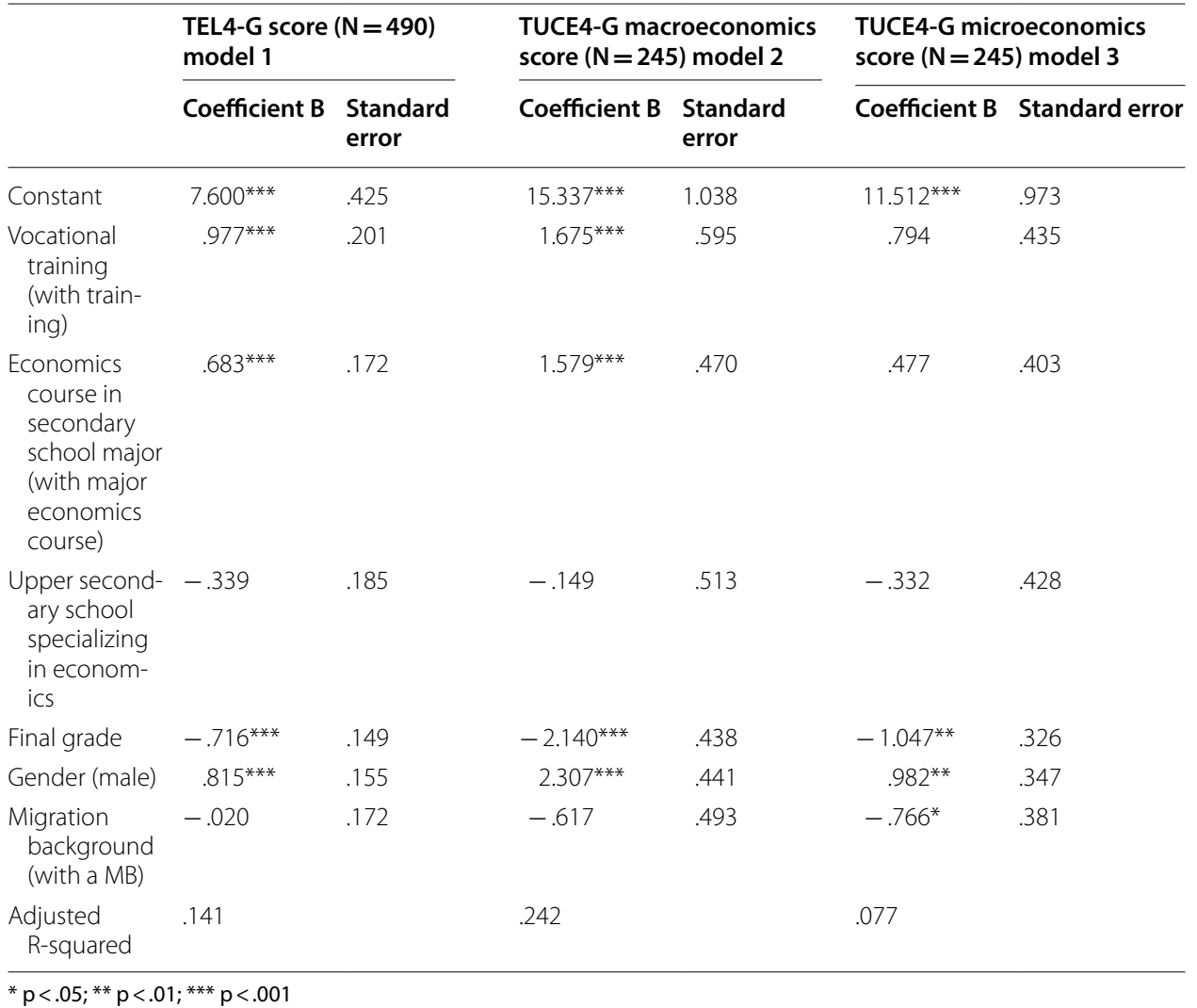

\section{Regression models}

As results of the analyses above indicate (see Table 2 in "Sample" section), differences in the relationship between person-related variables (i.e., gender, migration background and final grade) and performance on the 40 questionnaire items depended on the previous educational experiences (vocational training and/or a course in economics as a major subject at secondary school). To analyze this distribution, multiple linear regression were calculated in which learning opportunities and control variables were included. Table 4 shows a regression model for knowledge of each of the three content areas assessed.

As can be seen in Table 4 the effect of completing vocational training and/or a course in economics as a major subject at secondary school on performance on the TEL4-G items (model 1) was highly significant, even when taking into account the control variables. Here, a positive effect on economic knowledge can be assumed for both learning opportunities. On the contrary, attendance of a specialized upper secondary school compared to attendance of a standard upper secondary school shows no significant differences, whereas the coefficient $B$ has a negative sign, which is compatible with the findings of Trautwein et al. (2007). Model 1 explains $14.1 \%$ of the total variance (adjusted $\mathrm{R}^{2}$ ). As reported in other studies (see "Factors that influence the knowledge of economics of beginning university students" section), the male participants with an average of approximately .82 points performed significantly better than female students on the 
TEL4-G items. The final grade also correlates positively with the scores on the TEL4-G items. A participant with a grade of 1.3 could respond correctly to approximately .72 TEL4-G items more than a participant with a grade of 2.3. The control variable migration background had no significant effect $(\mathrm{p}=.906)$ on the scores on the TEL4-G items.

In the regression model 2 for the TUCE4-G items concerning macroeconomics, almost a quarter of the total variance could be explained (adjusted $R^{2}=24.2$ ). Completing vocational training and a course in economics as a major subject at secondary school also had a highly significant positive effect on knowledge of macroeconomics. Here also, attendance of a specialized upper secondary school has no significant influence compared to attendance of a standard upper secondary school, while the coefficient B again has a negative sign. Generally, participants who had completed vocational training achieved approximately 1.68 points and participants who had completed a course in economics as a major subject at secondary school achieved approximately 1.58 points more than participants who had not had these two learning opportunities. On the TUCE4-G items concerning macroeconomics, male participants scored an average of approximately 2.14 points more than female participants. Similarly, the participants' grade upon leaving school made a significant contribution to explaining this: On average, participants with a grade of 2 achieved approximately 2.14 points more on the TUCE4-G items concerning macroeconomics than participants with a grade of 3. Migration background is not significant in score on the TUCE4-G items concerning macroeconomics $(\mathrm{p}=.212)$.

With regard to the score on the TUCE4-G items concerning microeconomics, the completion of vocational training $(\mathrm{p}=.069)$, a course in economics as a major subject at secondary school $(\mathrm{p}=.238)$ and attendance of an upper secondary school specializing in economics $(\mathrm{p}=.439)$ had no significant effect on knowledge of microeconomics, and at $7.7 \%$, the covariates included could explain only a small proportion of the total variance. On average, male participants were more likely to solve an item $(+.98)$ correctly than female students. Similarly, the grade final grade was significant, whereby a participant with a grade of 2 was on average more likely to respond correctly to an item $(+1.05)$ than a participant with a grade of 3 . It was conspicuous that participants with a migration background scored significantly worse on TUCE4-G items concerning microeconomics $(\mathrm{p}=.046)$ than respondents without a migration background. The average score on the TUCE4-G items concerning microeconomics of these two groups was .8 points. ${ }^{7}$

\section{Discussion}

In this study the effects of economic education obtained prior to university studies on beginning students' knowledge in different content areas of economics were investigated while controlling for additional person-related variables. While the findings for general knowledge of economics, which was assessed using items from the TEL4-G, were in line with the results of previous studies, a different picture emerged for higherlevel knowledge of economics, which was assessed using items concerning macroeconomics and microeconomics from the TUCE4-G. Significant differences in knowledge

\footnotetext{
7 Models with interaction effects between the learning opportunities were also calculated (Aiken and West 1996; Fox 2008). However, based on the $5 \%$ significance level, these show no significant effects and are therefore disregarded hereafter. Similarly, the interaction effect models showed a lower adjusted R-squared, which implies a worse model specification in these models.
} 
of macroeconomics were found in favor of participants who had completed vocational training or a course in economics as a major subject at secondary school whereas differences in knowledge of microeconomics were only minor and not significant (see results of the $\mathrm{t}$ test and the regression model in "Histograms and t-tests" and "Regression models" sections). Completing vocational training or a course in economics as a major subject at secondary school therefore had an effect on general knowledge of economics and knowledge of macroeconomics, but not on knowledge of microeconomics. Attendance of an upper secondary school specializing in economics has no significant effect on neither of the three scores, whereas the coefficient $B$ has a negative sign in all three cases.

These findings should be examined critically due to the comparatively small sample resulting from the booklet design of the two content areas of the TUCE4-G. While the descriptive statistics of the sample are to a great extent consistent with official national statistics pertaining to higher education, this study was never designed to be a representative survey; rather the aim of this study was to gain preliminary insights into beginning university students' knowledge in the three main content areas of economics. Particularly the non-significant scores regarding attendance of a specialized upper secondary school should be critically examined.

The suitability of the two instruments for higher education study entry diagnostics in the domain of economics also can be estimated from the findings. Overall, combining items from different test instruments to assess knowledge appears to be advantageous. However, the findings indicate that it is not very target-oriented to use all the items on the TUCE4-G in their available form as a part of study entry diagnostics for beginning students. For example, in the microeconomics part, no participant was able to score more than 20 points out of the maximum score of 30 points. Some of the items from the TUCE4-G are therefore too difficult even for beginning students who have already utilized economic learning opportunities beforehand. Instead, it is more suitable to select items that build directly on the knowledge required for the TEL4-G in terms of content or that is rooted in secondary school curriculum. Therefore, future studies should aim to include a higher number of test items from the TEL4-G in combination with items from the TUCE4-G.

\section{Conclusions}

The findings of this study indisputably show that during commercial vocational training knowledge is imparted that, according to previous curricular analyses, can be considered study-relevant for economics degree courses and, to some extent, provides students with a foundation for learning about various economics-related topics such as those assessed using the TUCE4-G items concerning macroeconomics. The findings also indicate, however, that beginning students have a limited amount of study-relevant knowledge only. The generally rather low mean values of the scores on TUCE4-G items indicate this as well (see "Histograms and t-tests" section). It would be interesting to use this study as a basis to examine longitudinally whether the generally higher level of knowledge gained by completing vocational training or a course in economics as a major subject at secondary school has a positive influence on knowledge acquisition over the course of higher education studies. 
With regard to implications for higher education didactics, the findings of this study indicate that there is considerable heterogeneity in terms of knowledge of economics of beginning students in the field of business and economics. Study entry diagnostics of this sort are needed for designing higher education courses that will support beginning students who are disadvantaged due to a lack of prior education in economics (McAlpine and Weston 2000). In the sense of the curriculum-instruction-assessment triad by Pellegrino (2012) such study entry diagnostics provide a basis upon which curricula of economics degree courses can be planned and instructional methods can be chosen in a targeted manner. Although heterogeneity in the classroom is to be expected in degree courses in fields of study as popular as economics, such diversity in study-related knowledge poses a challenge for implementing technically innovative and potentially very effective instructional methods such as individualized learning pearls. Such methods should be tested and further developed so that instructors eventually can use them to provide beginning students with differentiated learning opportunities in the classroom and online regardless of their level of prior education in economics and thereby increase the likelihood of study success (Dimitrova et al. 2003; Oliver 2001).

From a didactics perspective, observing which contents posed particular difficulties for the students is an important insight for student-oriented teaching. Overall, as expected, the items from the TEL4-G were more likely to be solved correctly than items from the TUCE4-G. Within the TUCE4-G, the items concerning microeconomics were more difficult for students to solve than macroeconomics-related items (see "Results"). A closer examination of the three test parts (TEL4-G; TUCE4-G macro- and microeconomics) will provide interesting insights regarding the exact areas where participants showed shortcomings. Upon viewing the correct-response rates for items from the TEL4-G, it becomes apparent that particular difficulties occurred in the content areas "money and inflation" and "labor markets and income". One possible interpretation for this observation would be that these areas have a great overlap with students' personal finances. Personal finance contents are generally hardly covered in German economics curricula (Retzmann and Seeber 2016, p. 9). In the general education sector, only few references to this content area can be found (Happ et al. 2018; Happ and Förster 2017). First studies show that beginning university students have comparable deficits in their personal financial knowledge (Förster and Happ 2018). It is therefore comprehensible that beginning students have deficits in this area, which can provide an important point for subject-specific didactics.

In the macroeconomics part of the TUCE4-G, students had particular difficulties in the content area "monetary and fiscal policies". Correct-response rates of $>20 \%$ per item show that participants have major shortcomings in this area. Participants also struggled with the content area "policy debates", which seems rather surprising considering that school curricular primarily address economic topics from a political perspective (see "Factors that influence the knowledge of economics of beginning university students"). It is possible, however, that curricular hardly reach the depth required for a profound macroeconomic understanding. Out of the TUCE4-G items on microeconomics, the lowest correct-response rates were observed in items from two content areas, "markets and 
prices $^{8 "}$ and "theories of firm", where the correct-response rate lies below $20 \%$ per item for all items. This reveals substantial deficits in students' microeconomic knowledge and understanding. These finding clearly show that an in-depth macro- and microeconomic understanding can not be expected from any of the participants (irrespective of whether they completed an economics course as a major subject or a vocational training).

\section{Abbreviations}

CEE: council for economic education: SD: standard deviation; TEL4: test of economic literacy 4th version; TUCE4: test of understanding college economics 4th version; TEL4- G: test of economic literacy German version; TUCE4-G: test of understanding college economics German version; WiWiKom: modeling and measuring competencies in business and economics.

\section{Authors' contributions}

All authors contributed substantially to this work. $\mathrm{RH}$ and OZ-T developed the theoretical framework of the paper. Data analysis for this paper was conducted by MF and RH. All authors discussed the manuscript at all stages. All authors read and approved the final manuscript.

\section{Author details}

1 Department of Law, Business \& Economics, Chair of Business and Economics Education, Johannes Gutenberg University Mainz, Jakob-Welder-Weg 9, 55128 Mainz, Germany. ${ }^{2}$ Faculty of Social Sciences, Economics, and Business Administration, Chair for Business and Economics Education, Otto Friedrich University of Bamberg, Kärntenstraße 7, 96052 Bamberg, Germany.

\section{Acknowledgements}

We particularly thank the two anonymous reviewers who provided very detailed, constructive feedback and helpful guidance during the revision of this paper.

\section{Competing interests}

The authors declare that they have no competing interests.

\section{Availability of data and materials}

Not applicable. There is a copyright on the test instruments by the Council for Economic Education (CEE; US) and the data set cannot be shared.

\section{Consent for publication}

Not applicable.

\section{Ethics approval and consent to participate}

Taking part in the research project was entirely voluntary. All students consented to participate. A ethic committee was established at the end of 2014 at the department of business and economics at the University in Mainz. Until that point the design and the questionnaire was finished. If the editors wish a retrospective ethics approval of the anonymous, voluntary study, we can ask the ethics committee. We have still talked to a member of the ethics committee and he remarked no critical points in the questionnaire.

\section{Funding}

Not applicable

\section{Publisher's Note}

Springer Nature remains neutral with regard to jurisdictional claims in published maps and institutional affiliations.

Received: 26 January 2018 Accepted: 5 June 2018

Published online: 13 June 2018

\section{References}

Aiken LS, West SG (1996) Multiple regression: testing and interpreting interactions. Sage, Newbury Park

Anderson G, Benjamin D, Fuss MA (1994) The determinants of success in university introductory economics courses. J Econ Educ 25(2):99-119

Asarta C, Butters RB, Thompson E (2014) The gender question in economic education: is it the teacher or the test? PEER 9:1-19

\footnotetext{
${ }^{8}$ This covers contents such as "determinants of supply and demand", "utility", "elasticity", "price ceilings and floors" (Walstad and Rebeck 2008).

9 This content area includes, among others "revenues", "costs", "marginal analysis" and "market structures" (Walstad and Rebeck 2008).
} 
Bauer M, Hamm-Reinöhl A, Podes S, Riedel H (2016) Kolleg Politik und Wirtschaft (College politics and economics). C. C Buchner, Bamberg

Beck K, Krumm V (1994) Economic literacy in German-speaking countries and the United States: methods and first results of a comparative study. In: Walstad WB (ed) An international perspective on economic education. Kluwer, Boston, pp 183-201

Beck K, Krumm V, Dubs R (1998) Wirtschaftskundlicher Bildungs-Test (WBT) [Test of economic literacy (TEL)]. Hogrefe, Göttingen

Bouley F, Wuttke E, Schnick-Vollmer K, Schmitz B, Berger S, Fritsch S, Seifried J (2015) Professional competence of prospective teachers in business and economics education-evaluation of a competence model using structural equation modelling. Peabody J Educ 90(4):491-502

Brasfield DW, Harrison DE, McCoy JP (1993) The impact of high school economics on the college principles of economics course. J Econ Educ 24(2):99-111

Brückner S, Förster M, Zlatkin-Troitschanskaia O, Happ R, Walstad WB, Yamaoka M, Asano T (2015a) Gender effects in assessment of economic knowledge and understanding: differences among undergraduate business and economics students in Germany, Japan, and the United States. Peabody J Educ 90(4):503-518

Brückner S, Förster M, Zlatkin-Troitschanskaia O, Walstad WB (2015b) Effects of prior economic education, native language, and gender on economic knowledge of first year students in higher education: a comparative study between Germany and the USA. Stud High Educ 40(3):437-453

CENEVAL (2013) Guía para el sustentante Examen General para el Egreso de la Licenciatura en Economía. http://egel2 013.aexiuv.com/guias-egel/GuiaEGEL-ECONO.pdf. Accessed 03 Mar 2015

Chang PH (2005) Transformation of vocational secondary schools - a study of the vocational gymnasium in Germany. Barbara Budrich, Opladen

Chou CP, Bentler P (1995) Estimates and tests in structural equation modeling. In: Hoyle RH (ed) Structural equation modeling: concepts, issues, and applications. Sage, Thousand Oaks, pp 37-55

Cohen J (1988) Statistical power analysis for the behavioral sciences. Erlbaum, Hillsdale

Curran PJ, West SG, Finch JF (1996) The robustness of test statistics to nonnormality and specification error in confirmatory factor analysis. Psychol Methods 1(1):16-29

Dimitrova M, Sadler C, Hatzipanagos S, Murphy A (2003) Addressing learner diversity by promoting flexibility in e-learning environments. In: Proceedings of the 14th international workshop on database and expert systems applications. https://doi.org/10.1109/dexa.2003.1232037

Distel H, Feist T, Kraus E, Lüpertz V (2014) Betriebswirtschaftliches Handeln—Wirtschaftsgymnasium Jahrgangsstufen 1 und 2 (Business and economics practice-for economics-oriented upper secondary school, years 1 and 2), 6th edn. Europa-Lehrmittel, Haan-Gruiten

Dochy FRC, Segers M, Buehl MM (1999) The relation between assessment practices and outcomes of studies: the case of research on prior knowledge. Rev Educ Res 69(2):145-186

Eckhardt T, Eurydice (eds) (2017) The education system in the Federal Republic of Germany 2014/2015. Secretariat of the standing conference of the ministers of education and cultural affairs of the Länder in the Federal Republic of Germany, Bonn. https://www.kmk.org/fileadmin/Dateien/pdf/Eurydice/Bildungswesen-engl-pdfs/dossier_en_ebook .pdf. Accessed 07 May 2018

Educational Testing Service (ETS) (2014) Find out how to prove-and improve-the effectiveness of your economics program with the ETS Major field tests. http://www.ets.org/s/mft/pdf/mft_testdesc_economics_4emf.pdf. Accessed 31 Mar 2016

Elliott AC, Woodward WA (2007) Statistical analysis quick reference guidebook. Sage, Thousand Oaks

Engelhart K (2010) Sozialkunde Politik in der Sekundarstufe II (Social studies politics in upper secondary education). Schöningh, Braunschweig

Federal Statistical Office (2016) Studierende an Hochschulen - Wintersemester 2015/2016 (Students at universitieswinter term 2015/2016). Federal Statistical Office, Wiesbaden

Förster M, Happ R (2018) Studiengangsspezifische Unterschiede im finanziellen Wissen und Verstehen in Deutschland (Study course related differences in the knowledge and understanding of personal finance in higher education). Empirische Pädagogik 32(1):5-23

Förster M, Zlatkin-Troitschanskaia O, Happ R (2015a) Adapting and Validating the test of economic literacy to assess the prior economic knowledge of first-year students in business and economic studies in Germany (Discussion paper of the American economic association congress). AEA, Boston

Förster M, Zlatkin-Troitschanskaia O, Brückner S, Happ R, Hambelton RK, Walstad WB, Asano T, Yamaoka M (2015b) Validating test score interpretations by cross-national comparison comparing the results of students from Japan and Germany on an American test of economic knowledge in higher education. Zeitschrift für Psychologie 223(1):14-23

Fox J (2008) Applied regression analysis, linear models, and related methods, 2nd edn. Sage, Los Angeles

Georg W (2014) Gymnasium und Beruf. Zur Entstehung und Entwicklung beruflicher Gymnasien (Upper secondary school and profession. On the emergence and development of vocational upper secondary schools). Bildung und Erziehung 67(1):85-102

Gill AM, Gratton-Lavoie C (2011) Retention of high school economic knowledge and the effect of the California state mandate. J Econ Educ 42(4):319-337

Gravetter F, Wallnau L (2014) Essentials of statistics for the behavioral sciences. Wadsworth, Belmont

Hailikari T (2009) Assessing university students' prior knowledge. Implications for theory and practice. University of Helsinki, Department of Education Research Report, Helsinki, p 227

Happ R, Förster M (2017) The importance of controlling for socioeconomic factors when determining how vocational training and a secondary school economics class influence the financial knowledge of young adults in Germany. Zeitschrift für ökonomische Bildung 6:121-146

Happ R, Förster M, Zlatkin-Troitschanskaia O, Carstensen V (2016a) Assessing the previous economic knowledge of beginning students in Germany_implications for teaching economics in basic courses. CSEE 15(1):45-57 
Happ R, Zlatkin-Troitschanskaia O, Beck K, Förster M (2016b) Increasing heterogeneity in students' prior economic content knowledge-impact on and implications for teaching in higher education. In: Wuttke E, Seifried J, Schumann $\mathrm{S}$ (eds) Economic competence of young adults in European countries. Barbara Budrich Publishers, Opladen, pp $193-210$

Happ R, Schmidt S, Zlatkin-Troitschanskaia O, Förster M (2017) Einfluss des Migrationshintergrunds bei Studierenden auf den Fachwissenserwerb im wirtschaftswissenschaftlichen Studium —eine vergleichende Längsschnittstudie (The influence of migration background on higher education students' acquisition of content knowledge in business and economics studies - a comparative longitudinal study). Zeitschrift für Bildungsforschung 7(1):59-77

Happ R, Förster M, Rüspeler AK, Rothweiler J (2018) Young adults' knowledge and understanding of personal finance in Germany -interviews with experts and test-takers. CSEE 17(1):3-19. https://doi.org/10.1177/2047173417747601

Hartmann GB (2015) Gesamtwirtschaftliche Aspekte—Industrie (Macroeconomic aspects—industry), 9th edn. Merkur Verlag, Rinteln

Hessisches Kultusministerium (Hessian Ministry for Education and Cultural Affairs) (2017a) Schulbücherkatalog für berufliche Schulen (Textbook Catalogue for Vocational Schools). https://kultusministerium.hessen.de/sites/default/files/ media/hkm/schulbuecherkatalog_fuer_berufliche_schulen_stand_01.08.2017.pdf. Accessed 04 May 2018

Hessisches Kultusministerium (Hessian Ministry for Education and Cultural Affairs) (2017b) Schulbücherkatalog für allgemeinbildende Schulen und Schulen für Erwachsene (Textbook catalogue for non-specialized schools and adult schools). https://kultusministerium.hessen.de/sites/default/files/media/hkm/schulbuecherkatalog_fuer_berufliche _schulen_stand_01.08.2017.pdf. Accessed 04 May 2018

Hillmert S, Jacob M (2003) Social inequality in higher education. Is vocational training a pathway leading to or away from university? Eur Sociol Rev 19(3):319-334

Ho AD, Yu C (2015) Descriptive statistics for modern test score distributions: skewness, kurtosis, discreteness, and ceiling effects. Educ Psychol Meas 75(3):365-388

Hoyt GM, McGoldrick K (eds) (2012) International handbook on teaching and learning economics. Edward Elgar, Cheltenham

Hurrelmann K (2009) Ökonomische Bildung an Schulen: ein innovativer Ansatz zur Förderung auch der benachteiligten Schülerlnnen (Economic education at schools: an innovative approach for fostering even disadvantaged students). ZWD-Mag 11:8-12

IBM Corp (2014) IBM SPSS statistics for windows, version 23.0. IBM Corp, Armonk

Klein O, Biedinger N, Becker B (2014) The effect of reading aloud daily - differential effects of reading to native-born German and Turkish-origin immigrant children. Res Soc Stratif Mobil 38:43-56

Kristen C, Reimer D, Kogan I (2008) Higher education entry of Turkish immigrant youth in Germany. Int J Comp Sociol 49(2-3):127-151

Krugman P, Wells R (2013) Economics. Worth, New York

Kuh GD, Kinzie J, Buckley J, Bridges B, Hayek J (2007) Piecing together the student success puzzle: research, propositions, and recommendations. ASHE higher education report, vol 32(5). Jossey-Bass, San Francisco

Lorz O, Siebert H (2007) Einführung in die Volkswirtschaftslehre (Introduction to economics), 15th edn. Kohlhammer, Stuttgart

LüpertzV (2018) Problemorientierte Einführung in die Volkswirtschaftslehre (A problem-oriented introduction to economics), 9th edn. Winklers, Braunschweig

Mankiw NG, Taylor MP (2011) Economics. South-Western Cengage Learning, Andover

McAlpine L, Weston C (2000) Reflection: issues relate to improving professors'teaching and students' learning. Instr Sci 28(5-6):363-385

Ministerium für Bildung (Ministry for Education) (2017) Das berufliche Gymnasium (Vocational upper secondary school). Ministerium für Bildung, Mainz

Möhlmeier H, Skorzenski F, Wierichs G, Wurm G (2015) Allgemeine Wirtschaftslehre für den Bankkaufmann/die Bankkauffrau (General economics for bankers), 11th edn. Bildungsverlag EINS, Troisdorf

Moore DS, McCabe GP (2003) Introduction to the practice of statistics. W. H. Freeman and Company, New York

National Center for Education Statistics (NCES) (2006) The nation's report card: economics 2006-national assessment of educational progress at grade 12. National Center for Education Statistics, US Department of Education, Washington, D.C

Organisation for Economic Cooperation and Development (OECD) (2011) Tuning-AHELO conceptual framework of expected and desired learning outcomes in economics, vol 59. OECD Education Working Papers. OECD Publishing, Paris. https://doi.org/10.1787/5kghtchwb3nn-en

Oliver RG (2001) Developing e-learning environments that support knowledge construction in higher education. In: Stoney S, Burn J (eds) Working for excellence in the e-conomy. We-B Centre, Churchlands, pp 407-416

Pädagogisches Landesinstitut Rheinland-Pfalz (2018) Schulbuchkatalog 2018/2019 [Pedagogical State Institute Rhineland-Palatinate (2018) Textbook catalogue 2018/2019]. http://Imf-online.rlp.de/fuer-schulen/schulbuchkatalo g.html. Accessed 04 May 2018

Parker K (2006) The effect of students characteristics on achievement in introductory microeconomics in South Africa. S Afr J Econ 74(1):137-149

Pellegrino JW (2012) The design of an assessment system focused on student achievement. A learning sciences perspective on issues of competence, growth and measurement. In: Bernholt S, Neumann K, Nentwig P (eds) Making it tangible-learning outcomes in science education. Münster, Waxmann, pp 79-107

Prins FJ, Veenman MVJ, Elshout JJ (2006) The impact of intellectual ability and metacognition on learning: new support for the thresholds of problematicity theory. Learn Instr 16(4):374-387

Retzmann T, Seeber G (2016) Financial education in general education schools: a competence model. In: Aprea C, Wuttke E, Breuer K et al (eds) International handbook of financial literacy. Springer Singapore, Singapore, pp 9-23

Salentin K (2014) Sampling the ethnic minority population in Germany. The background to "migration background". Methods Data Anal J Quant Methods Surv Methodol 8(1):25-52

Samuelson PA, Nordhaus WD (2010) Economics. McGraw Hill, Boston 
Scheller P, Isleib S, Sommer D (2013) Studienanfängerinnen und Studienanfänger im Wintersemester 2011/12 (Beginning students in the winter semester of 2011/2012). Tabellenband. HIS, Hannover

Schumann S, Eberle F, Oepke F (2013) Ökonomisches Wissen und Können am Ende der Sekundarstufe Il: Effekte der Bildungsgang-, Klassen- und Geschlechtszugehörigkeit (Economic knowledge and skills in upper secondary school: effects of school type, year and gender). In: Faßhauer U, Fürstenau B, Wuttke E (eds) Jahrbuch der berufsund wirtschaftpädagogischen Forschung 2013 (Yearbook of vocational and economic education research 2013). Barbara Buderich, Opladen, pp 35-46

Sczesny C, Lüdecke-Plümer S (1998) Ökonomische Bildung Jugendlicher auf dem Prüfstand: diagnose und Defizite (Economic education of young adults at examination level: diagnosis and deficits). Zeitschrift für Berufs-und Wirtschaftspädagogik 94(3):403-420

Shim S, Barber BL, Card NA, Xiao JJ, Serido J (2009) Financial socialization of first-year college students: the roles of parents, work, and education. J Youth Adolesc 39(12):1457-1470

Sugarman J, Morris-Lange S, McHugh M (2016) Improving education for migrant-background students. Migration Policy Institut, Washington, D.C

Trautwein U, Köller O, Lehmann R, Lüdtke O (2007) Schulleistungen von Abiturienten: Regionale, schulformbezogene und soziale Disparitäten (Performance of upper secondary school graduates: regional, school-related and social disparities). Waxmann Verlag, Münster

Uthmann C (2009) Studierendenauswahl—Erprobung und Evaluation eines multidimensionalen testdiagnostischen Verfahrens zur Studienerfolgsprognose an der Fachhochschule Heidelberg (Student selection—proving and evaluation of a multidimensional diagnostic test battery for prediction of study success at the university of applied sciences Heidelberg). Südwestdeutscher Verlag für Hochschulschriften, Saarbrücken

Van den Berg MN, Hofman WHA (2005) Student success in university education: a multi-measurement study of the impact of student and faculty factors on study progress. High Educ 50(3):413-446

Vidal R (2013) Measurement of learning outcomes in higher education: the case of Ceneval in Mexico. In: Blömeke S, Zlatkin-Troitschanskaia O, Kuhn C, Fege J (eds) Modeling and measuring competencies in higher education: tasks and challenges. Sense Publishers, Rotterdam, pp 137-146

Walstad WB, Rebeck K (2008) The test of understanding of college economics. Am Econ Rev 98(2):547-551

Walstad WB, Watts M, Rebeck K (2007) Test of understanding in college economics: examiner's manual. National Council on Economic Education, New York

Walstad WB, Rebeck K, Butters RB (2013) The test of economic literacy: development and Results. J Econ Educ 44(3):298-309

Yousfi S, Böhme HF (2012) Principles and procedures of considering item sequence effects in the development of calibrated item pools: conceptual analysis and empirical illustration. Psychol Test Assess Model 54(4):366-396

Zlatkin-Troitschanskaia O, Förster M, Brückner S, Happ R (2014) Insights from a German assessment of business and economics competence. In: Coates $\mathrm{H}$ (ed) Higher education learning outcomes assessment-international perspectives. Peter Lang, Frankfurt/Main, pp 175-197

Zlatkin-Troitschanskaia O, Förster M, Schmidt S, Brückner S, Beck K (2015) Erwerb wirtschaftswissenschaftlicher Fachkompetenz im Studium - Eine mehrebenenanalytische Betrachtung von hochschulischen und individuellen Einflussfaktoren (Acquisition of economic competence over the course of studies-a multilevel analysis of personal and higher education influence factors). In: Blömeke S, Zlatkin-Troitschanskaia (eds) Kompetenzen von Studierenden (Beiheft) [Students' competences (Supplement)]. Zeitschrift für Pädagogik 61 (1):116-135

Zlatkin-Troitschanskaia O, Schmidt S, Brückner S, Förster M, Yamaoka M, Asano T (2016) Macroeconomic knowledge of higher education students in Germany and Japan - a multilevel analysis of contextual and personal effects. Assess Eval High Educ 41(5):787-801. https://doi.org/10.1080/02602938.2016.1162279

Zlatkin-Troitschanskaia O, Pant HA, Lautenbach C, Molerov D, Toepper M, Brückner S (2017) Modeling and measuring competencies in higher education: approaches to challenges in higher education policy and practice. Springer VS, Wiesbaden

\section{Submit your manuscript to a SpringerOpen ${ }^{\circ}$ journal and benefit from:}

- Convenient online submission

- Rigorous peer review

- Open access: articles freely available online

High visibility within the field

- Retaining the copyright to your article

Submit your next manuscript at $\mathbf{s p r i n g e r o p e n . c o m ~}$ 